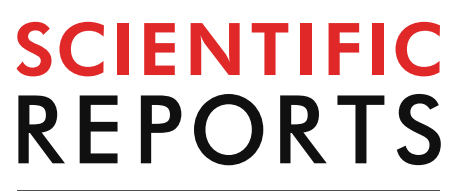

natureresearch

Check for updates

\title{
Gram-positive bacteria
} control the rapid anabolism of protein-sized soil organic nitrogen compounds questioning the present paradigm

\author{
Kirsten Lønne Enggrob ${ }^{1}$, Thomas Larsen², Leanne Peixoto ${ }^{1}$ \& Jim Rasmussen ${ }^{1 凶}$
}

The cycling of especially large size organic nitrogen $(\mathrm{N})$ from plants into stable microbial derived soil organic carbon (C) and $\mathrm{N}$ pools is understudied, in spite of organic $\mathrm{N}$ composing $90 \%$ of soil $\mathrm{N}$ and the intimate link between organic $\mathrm{N}$ and soil $\mathrm{C}$ stabilization. We investigated the fate of peptide-size and protein-size organic $\mathrm{N}$ fractions in soils from two long-term field experiments markedly differing in conditions for microorganisms. We combined amino acid stable isotope probing (AA-SIP) fingerprinting with PLFA-SIP to trace organic $\mathbf{N}$ into the soil microbial biomass. Contrary to the present paradigm, we found for both soils that greater molecular size did not protect against decomposition of these compounds neither did protection via strong sorption to the soil mineral phase. Instead, we found strong evidence that gram-positive bacteria are the key actors in the decomposition of protein-sized nitrogen compounds and that amino acids bound in large organic nitrogen compounds directly contribute to the build-up of bacterial tissue. We conclude that when large organic nitrogen compounds are dissolved, turnover occurs rapidly, irrespective of molecular size, and the bacterial incorporation of these rapid cycling compounds makes an important contribution to soil organic matter formation.

Turnover and stabilization of soil carbon (C) and nitrogen $(\mathrm{N})$ are critical processes for enhancing $\mathrm{N}$ use efficiency in cultivated soils and mitigating increasing atmospheric loads of greenhouse gases through soil $\mathrm{C}$ sequestration ${ }^{1}$. Nitrogen plays a pivotal role for C-cycling in soils because one-third of stored $\mathrm{C}$ is bound in compounds containing $\mathrm{N}^{2}$. Thus, to enhance soil $\mathrm{C}$ storage it is vital to improve our understanding of the fate of organic $\mathrm{N}$ compounds. The present view on soil organic matter (SOM) formation ${ }^{3,4}$ implies that microbial turnover is key to $\mathrm{C}$ and $\mathrm{N}$ stabilization ${ }^{5,6}$, which requires insight in the short-term cycling of labile organic compounds. During litter decomposition, small plant-derived compounds, like amino acids and sugars, turn over within hours or days ${ }^{7,8}$, which may contribute to the build-up of microbial biomass ${ }^{9}$ and eventual SOM stabilization in the microbial necromass ${ }^{10,11}$ on mineral surfaces ${ }^{12,13}$. However, the turnover rates of the larger $(>0.6 \mathrm{kDa})$ organic $\mathrm{N}$ compounds derived from plants and their role in the formation of SOM is only scarcely examined.

Soil organic matter is composed of progressively decomposing organic compounds in a continuum of size classes $^{4}$. In the prevailing soil organic matter cycling paradigm, the soil continuum model, Lehmann and Kleber ${ }^{4}$ formulates a generally accepted distinction between small biopolymers $(<0.6 \mathrm{kDa})$ that can be directly assimilated by microorganisms and larger compounds $(>0.6 \mathrm{kDa})$ that require extracellular depolymerization prior to microbial assimilation. Since proteins, the major form of organic $\mathrm{N}$, are larger than $0.6 \mathrm{kDa}^{14}$, the soil continuum model suggests that depolymerization governs the turnover of organic $\mathrm{N}$ from proteins to peptides and amino acids ${ }^{15}$. The slower turnover of larger $\mathrm{N}$ compounds ${ }^{16,17}$ has also been attributed to the strong retention or sorption of proteins to the soil mineral phase ${ }^{17,18}$. However, our understanding of organic $\mathrm{N}$ turnover

${ }^{1}$ Department of Agroecology, Faculty of Science and Technology, Aarhus University, Post Box 50, 8830 Tjele, Denmark. 'Department of Archaeology, Max Planck Institute for the Science of Human History, Jena, Germany. ${ }^{\circledR}$ email: jim.rasmussen@agro.au.dk 


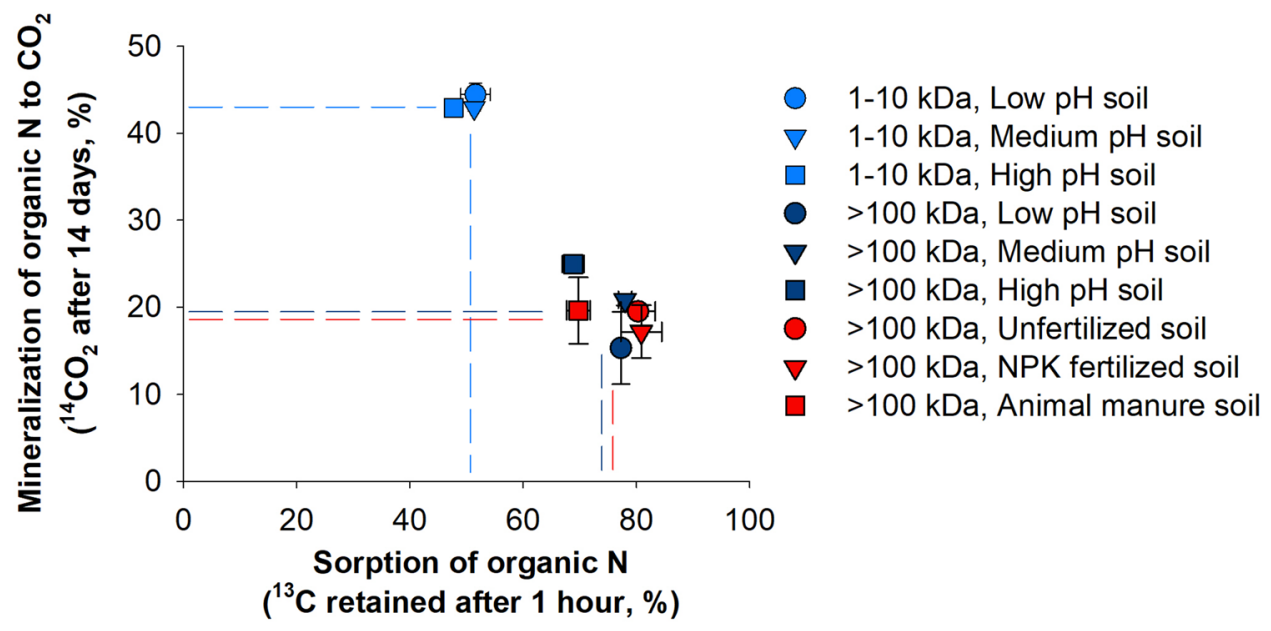

Figure 1. Sorption versus mineralization of large organic N. Sorption after $1 \mathrm{~h}$ and mineralization after 14 days of large organic $\mathrm{N}$ (1-10 kDa organic fraction in light blue; $>100 \mathrm{kDa}$ organic fraction in dark blue and red) in the Jyndevad soils (light and dark blue) at three pHCaCl2 levels: low at pH 3.6 (circle), medium at pH 5.4 (triangle down), and high at $\mathrm{pH} 7.1$ (square), and for the largest organic $\mathrm{N}$ fraction also in the Askov soils (red) at three fertility levels: unfertilized (circle), NPK mineral fertilizer (triangle down), and animal manure (square) since 1894. Error bars are s.e.m. $(\mathrm{n}=4)$.

remains incomplete because until now studies have focused exclusively on tracking the fate of biopolymers or used indirect indices for the larger protein-sized compounds focusing exclusively on mineralization and sorption over shorter time frames (two weeks) ${ }^{16}$. It has also been suggested that peptides are also strongly bound to the soil mineral phase $e^{2}$, but it is not clear whether amino acids bound in these peptides are bound in the original form or in microbial necromass ${ }^{11}$.

Therefore, the objective of this study was to determine the mechanisms controlling large molecular weight $(\mathrm{Mw})$ organic $\mathrm{N}$ cycling in soil, we added triple-labeled $\left({ }^{14} \mathrm{C},{ }^{13} \mathrm{C},{ }^{15} \mathrm{~N}\right)$ white clover sap to study the short-term fate of non-structural organic $\mathrm{N}$ compounds in two molecular size classes above the $0.6 \mathrm{kDa}$ threshold (peptide size class, $1-10 \mathrm{kDa}$, and protein size class, $>100 \mathrm{kDa}$ ) for direct microbial assimilation in topsoils from two renowned long-term field experiments (LTE) in Denmark ${ }^{19}$. The two LTE sites have contrasting management strategies; the Jyndevad LTE has manipulated liming and phosphorus fertilization since $1942^{20}$ and the Askov LTE have treatments with animal manure and mineral fertilizer since $1894^{21}$. The utilization of these unique LTE not only aims to exemplify the legacy effect of these management practices on the fate of organic $\mathrm{N}$, but to further facilitate a broadened contextual understanding of the mechanisms controlling the fate of organic $\mathrm{N}$ under different environmental conditions. Specifically, we determined organic $\mathrm{N}$ sorption and degradation versus retention of two size-fractions of organic $\mathrm{N}$ compounds with AA-SIP fingerprinting ${ }^{19}$, and identified the active microbial groups degrading the organic $\mathrm{N}$ compounds with PLFA-SIP ${ }^{22}$.

\section{Results}

Organic $\mathbf{N}$ is not retained in original form. To determine whether sorption controls degradation of large organic $\mathrm{N}$ compounds in soils from both LTE sites (Table S1 and S2), we quantified the accumulated respiration over a 14 day period relative to the removal of labeled $\left({ }^{13} \mathrm{C},{ }^{15} \mathrm{~N}\right)$ organic $\mathrm{N}$ compounds from soil solution after one hour. For the $1-10 \mathrm{kDa}$ and $>100 \mathrm{kDa}$ fractions, we found a negative correlation between respiration and sorption of total organic $\mathrm{N}$ showing that the larger the organic $\mathrm{N}$ fraction the stronger it is sorped to the soil (Fig. 1), thus supporting that microbial decomposition is controlled by the accessibility of organic $\mathrm{N}^{23,24}$. To validate this, we determined the degradation of the added organic $\mathrm{N}$ compounds by analyzing the isotopic values of soil-bound amino acids from the two size fractions (Fig. $2 \mathrm{a}-\mathrm{f}$ ). Low recoveries of the individual amino acids would signify that the organic $\mathrm{N}$ compounds were degraded rather than retained in their original form and a decoupling of the ${ }^{13} \mathrm{C}$ and ${ }^{15} \mathrm{~N}$ tracers would show that the organic $\mathrm{N}$ had been undergoing metabolism. Across all $\mathrm{pH}$ levels and organic $\mathrm{N}$ fractions, the recovery across individual amino acids were $0-20 \%$ for the ${ }^{15} \mathrm{~N}$ tracer and $1-30 \%$ for the ${ }^{13} \mathrm{C}$ tracer with significant decoupling of the remaining ${ }^{13} \mathrm{C}$ and ${ }^{15} \mathrm{~N}$ in individual amino acids (Fig. 2a-f). Of all the amino acids, leucine, lysine, phenylalanine had the lowest recoveries (Fig. 2a-f). It is unlikely that our low recovery of the dual-labeled amino acids is associated with the hydrolysis procedure ${ }^{25}$ as the isotopic ratios of amino acids are unaffected by amino acid decomposition during hydrolysis ${ }^{19}$. Further, despite the pronounced but varying degree of sorption of both added organic $\mathrm{N}$ size classes to the soil matrix it is highly unlikely that chemical sorption of the originally added amino acids bound in peptides and proteins explains the low recovery as such processes would result in similar or consistent recoveries across all amino acids.

Greater molecular size does not protect against decomposition. Amino acids with more complex biosynthetic pathways (e.g. leucine, lysine, phenylalanine) were decomposed at a greater rate than the simpler 


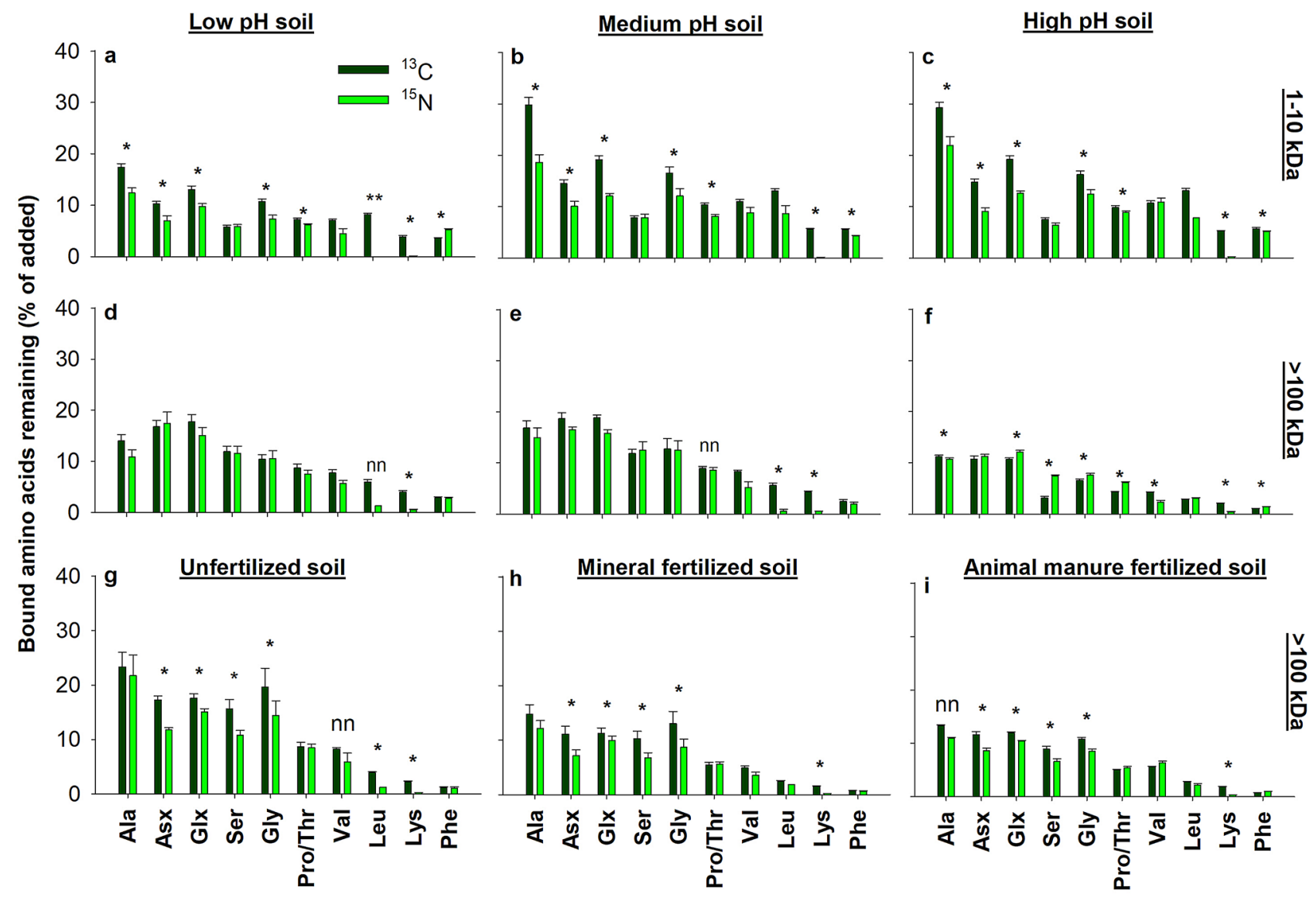

Figure 2. Organic $\mathrm{N}$ derived amino acids remaining in soil. Intact ${ }^{13} \mathrm{C}$ or ${ }^{15} \mathrm{~N}$ labeled amino acids remaining in $\%$ of added amino acids bound in either the peptide-sized $(1-10 \mathrm{kDa}, \mathbf{a}-\mathbf{c})$ and protein-sized $(>100 \mathrm{kDa}, \mathbf{d}-\mathbf{f}$ and $\mathbf{g}-\mathbf{i}$ ) organic $\mathrm{N}$ in Jyndevad soils at low $(\mathbf{a}, \mathbf{d})$, medium $(\mathbf{b}, \mathbf{e})$ and high $\mathrm{pH}$ soils $(\mathbf{c}, \mathbf{f})$, and in Askov soils being unfertilized (g), mineral fertilized (h) and fertilized with animal manure (i) since 1894. Significant differences in $\%{ }^{13} \mathrm{C}$ and ${ }^{15} \mathrm{~N}$-labed amino acids remaining are marked by an asterisk; a double asterisk indicates no ${ }^{15} \mathrm{~N}$ data; ' $\mathrm{nn}$ ' indicates non-normal distribution (error bars are s.e.m., $\mathrm{n}=4$ ). Amino acids are organized from left on right with increasing number of steps in their biosynthesis.

amino acids (e.g. alanine, asparagine/aspartate, glutamine/glutamate) (Fig. 2), which diverges from the expected direct anabolic microbial use of complex amino acids to reduce energy for de novo synthesis ${ }^{26}$. The results can neither be explained by different additions of these specific amino acids in the 1-10 and $>100 \mathrm{kDa}$ fractions (Fig. S1a) nor by changes in soil amino acid composition upon organic $\mathrm{N}$ addition (Fig. S2d-f). It is also notable that more amino acids remained in the $1-10 \mathrm{kDa}$ than $>100 \mathrm{kDa}$ fractions at Jyndevad medium and high $\mathrm{pH}$ soils further underlining that greater molecular size does not protect against decomposition. Moreover, ${ }^{13} \mathrm{C}$ and ${ }^{15} \mathrm{~N}$ decoupling were highest for the $1-10 \mathrm{kDa}$ fraction with more ${ }^{13} \mathrm{C}$ than ${ }^{15} \mathrm{~N}$ remaining at all Jyndevad $\mathrm{pH}$ levels. The most likely explanation for this decoupling is a higher rate of deaminating amino-groups during microbial metabolism ${ }^{27}$ than catabolizing amino acid $\mathrm{C}$ skeletons. Further, the $\mathrm{C}$ and $\mathrm{N}$ decoupling was highest for amino acids associated with aminotransferases, thus supporting that bacterial cells potentially incorporate intact amino acids from the soil medium. In other words, simpler amino acids such as alanine and asparagine was most likely incorporated intact into microbial tissue to a greater extent than more complex amino acids such as lysine and phenylalanine. Interestingly, simpler amino acids including alanine, asparagine/aspartate, glutamine/glutamate, and glycine are typically among the most abundant constituents of the peptidoglycan layers of bacterial cell walls ${ }^{28-30}$. Hence, our findings show that substantial incorporation of organic $\mathrm{N}$ by microbial cell walls is plausible.

To test whether the substantial decomposition of the $>100 \mathrm{kDa}$ organic $\mathrm{N}$ fraction in the Jyndevad soils can be attributed to soil specific conditions, we also incubated the Askov LTE soils with the protein-sized fraction $(>100 \mathrm{kDa})$. Soil from Askov is more clayey than the Jyndevad soils ${ }^{21}$ (Table S1 and S2), and the LTE treatments have resulted in different microbial communities ${ }^{31,32}$ and fertility levels ${ }^{33}$. The decomposition pattern of the $>100 \mathrm{kDa}$ fraction across the fertility levels of the Askov soils resembled those observed among the different $\mathrm{pH}$ levels of the Jyndevad soils (Fig. $2 \mathrm{~d}-\mathrm{h}$ ). Specifically, less than $25 \%$ of the ${ }^{13} \mathrm{C}$ and ${ }^{15} \mathrm{~N}$ bound in amino acids remained after two weeks among all three fertility levels (Fig. $2 \mathrm{~g}-\mathrm{h}$ ) and thus substantiating the decomposition of large organic $\mathrm{N}$ compounds, and the presence of an equilibrium between sorbed and dissolved organic $\mathrm{N}$. This is particularly remarkable as the soil unfertilized since 1894 exhibits an exceedingly strong potential for sorption $^{34}$ as the mineral surfaces are unsaturated with organic matter ${ }^{35}$. 
Gram-positive bacteria are key players in organic $\mathbf{N}$ turnover. To identify the microbial groups active in organic $\mathrm{N}$ turnover, we determined the incorporation of ${ }^{13} \mathrm{C}$ in PLFA biomarkers and found that bacteria dominated the specific incorporation of ${ }^{13} \mathrm{C}$ from both the $1-10 \mathrm{kDa}$ and $>100 \mathrm{kDa}$ fractions across all soils (Fig. 3c-e). Both bacteria and fungi have the capacity to facilitate exo-enzymatic decomposition with grampositive bacteria and fungi typically contributing to the degradation of complex compounds and gram-negative bacteria generally decomposing lower $\mathrm{Mw}$ compounds ${ }^{36}$. The specific incorporation of ${ }^{13} \mathrm{C}$ in microbial PLFA from the protein-sized organic $\mathrm{N}$ compounds showed a surprisingly similar pattern across all Jyndevad $\mathrm{pH}$ levels (Fig. 3d) and Askov fertilizer treatments (Fig. 3e). In all soils, gram-positive bacteria had a significantly higher specific ${ }^{13} \mathrm{C}$ incorporation from the $>100 \mathrm{kDa}$ fraction than gram-negative bacteria and subsequently higher ${ }^{13} \mathrm{C}$ incorporation than fungi. Low soil $\mathrm{pH}$ is generally considered to reduce bacterial activity, thus enhancing the relative importance of fungal activity ${ }^{37}$. Although the fungal and gram-negative bacterial activity (Fig. 3) and specific biomass (Fig. S3) responded to organic $\mathrm{N}$ addition, the higher activity of gram-positive bacteria on protein-sized organic $\mathrm{N}$ compounds show that this group of bacteria must exhibit the capacity for both proteolytic and uptake mechanisms to outcompete other microbial groups for protein-derived organic N. The production of extracellular enzymes is expected to be greater in gram-positive than in gram-negative bacteria where enzymes to a larger extent accumulate in the periplasmic space rather than being exuded ${ }^{38}$. Furthermore, some previous studies show that gram-positive bacterial species can directly assimilate organic $\mathrm{N}$ well above the $0.6 \mathrm{kDa}$ threshold ${ }^{39,40}$. In this study, we found evidence to suggest that the gram-positive bacterial group has the potential to outcompete both gram-negative and fungal groups in a two-step process involving decomposition of protein-sized $\mathrm{N}$ and subsequently a direct assimilation of the released peptide helixes (Fig. 4). Gram-negative bacteria requiring organic $\mathrm{N}$ smaller than the $0.6 \mathrm{kDa}$ threshold for assimilation could potentially scavenge for any additional peptide $\mathrm{N}$ for subsequent decomposition. A similar mechanism could apply for the $1-10 \mathrm{kDa}$ fraction, where the specific ${ }^{13} \mathrm{C}$ incorporation showed an equivalent microbial activity among the gram-positive and gram-negative bacteria, but greater fungal activity than observed for the $>100 \mathrm{kDa}$ fraction (Fig. 3c). The $1-10 \mathrm{kDa}$ fraction most likely contained labeled C-compounds other than organic $\mathrm{N}$, which could potentially have contributed to the ${ }^{13} \mathrm{C}$ incorporation in the microbial biomarkers. This may further explain the ${ }^{13} \mathrm{C}$ incorporation in the fungal biomarker for this organic $\mathrm{N}$ fraction. Thus, the results suggest that the direct assimilation above the $0.6 \mathrm{kDa}$ threshold may be more prevalent for gram-positive bacteria than previously considered or described, and importantly the PLFA-SIP identifies such a microbial group containing a repertoire of mechanisms capable of actively utilizing and resulting in a rapid turnover of protein-sized $\mathrm{N}$.

\section{Discussion}

Our results challenge the soil continuum model stating that soil organic $\mathrm{N}$ turnover follows a continuum where higher Mw organic N needs to be degraded extracellularly into lower Mw compounds to be directly assimilated by microorganisms and plants ${ }^{4,6,15}$. Compared to low Mw compounds, high Mw compounds are thought to be more protected against degradation because of stronger sorption to the substrate ${ }^{4,18}$, spatial separation of exoenzymes from the substrate ${ }^{3,41}$, or by blockage of the enzyme reactive sites ${ }^{17}$. However, in all treatments, we saw a rapid degradation of the organic $\mathrm{N}$ compounds irrespective of molecular size. Such rapid dissipation of protein-sized organic $\mathrm{N}$ could be expected in fertile agricultural soils ${ }^{15}$. However, the remaining organic $\mathrm{N}$ was comparably low in the low productivity soil (low pH or unfertilized since 1894) with a lower microbial biomass as in the more fertile soils. This suggests that the ability of the microbial biomass displayed the capacity for the decomposition of large size organic $\mathrm{N}$ in these soils and that the high sorption of $>100 \mathrm{kDa}$ organic $\mathrm{N}$ in all soils did not influence the exceedingly high turnover of the added compounds. Thus, we demonstrate that depolymerization of proteins is not per se the rate-limiting step in large size organic $\mathrm{N}$ turnover, neither is sorption of protein-sized organic $\mathrm{N}$ to the soil mineral phase. In relation to the latter, we show that sorbed organic $\mathrm{N}$ is in equilibrium with the soil solution where dissolved organic $\mathrm{N}$ compounds are rapidly turned over (i.e. sorption is not protecting the compounds). Rather, part of plant-derived protein must upon incorporation in soil, at least short-term, be physically protected in plant cell structures, requiring degradation prior to the turnover of proteins. Hence, in contrast to the presently viewed importance of proteolytic enzymes ${ }^{42,43}$, other enzyme classes targeting e.g. complex $\mathrm{C}$ compounds may play a pivotal role in the eventual turnover of bound organic $\mathrm{N}$. In the long term, parts of the structurally bound organic $\mathrm{N}$ may be physically protected in particulate organic matter predominately of plant origin ${ }^{34}$.

To study the stabilization of plant-derived C, Liang, et al. ${ }^{6}$ differentiates between in vivo turnover and ex vivo modification taking place inside or outside a microbial cell. The rapid and almost complete dissipation of all large size organic $\mathrm{N}$ fractions found in the present study and the incorporation of organic $\mathrm{N}$ derived ${ }^{13} \mathrm{C}$ into bacterial PLFAs point to in vivo turnover as the dominant route of decomposition. The turnover of $>100 \mathrm{kDa}$ organic $\mathrm{N}$ was dominated by gram-positive bacteria, which contain the exo-enzymatic tools to degrade these large compounds. Therefore, the potential for ex vivo modification should in theory be higher for the $>100 \mathrm{kDa}$ organic $\mathrm{N}$ as would retention of modified compounds to the soil mineral phase. However, our data does not support this, but rather large organic $\mathrm{N}$ primarily contributes to SOM formation via build-up of microbial tissue.

In conclusion, incorporation of $\mathrm{C}$ and $\mathrm{N}$ in the short-chained peptides of bacterial cell walls potentially results in longer-term storage of plant-derived C. Our study provides strong evidence for the hypothesis that $\mathrm{C}$ and $\mathrm{N}$ from labile compounds persist in soil ${ }^{5}$, but rather than persisting due to protection of the original compounds ${ }^{3}$, the $\mathrm{C}$ and $\mathrm{N}$ persist due to the incorporation via anabolic processes into microbial cell walls. Furthermore, the rapid turnover of large molecular size organic $\mathrm{N}$ compounds in our study necessitates a distinction between organic $\mathrm{N}$ contained inside the cell (non-structural ${ }^{5}$ ) and within cell structures when predicting the release of plant-available $\mathrm{N}$ from plant residues. Additionally, non-structural $\mathrm{N}$ inside microbial cells should be considered as a temporary pool that is highly prone to rapid decomposition. 

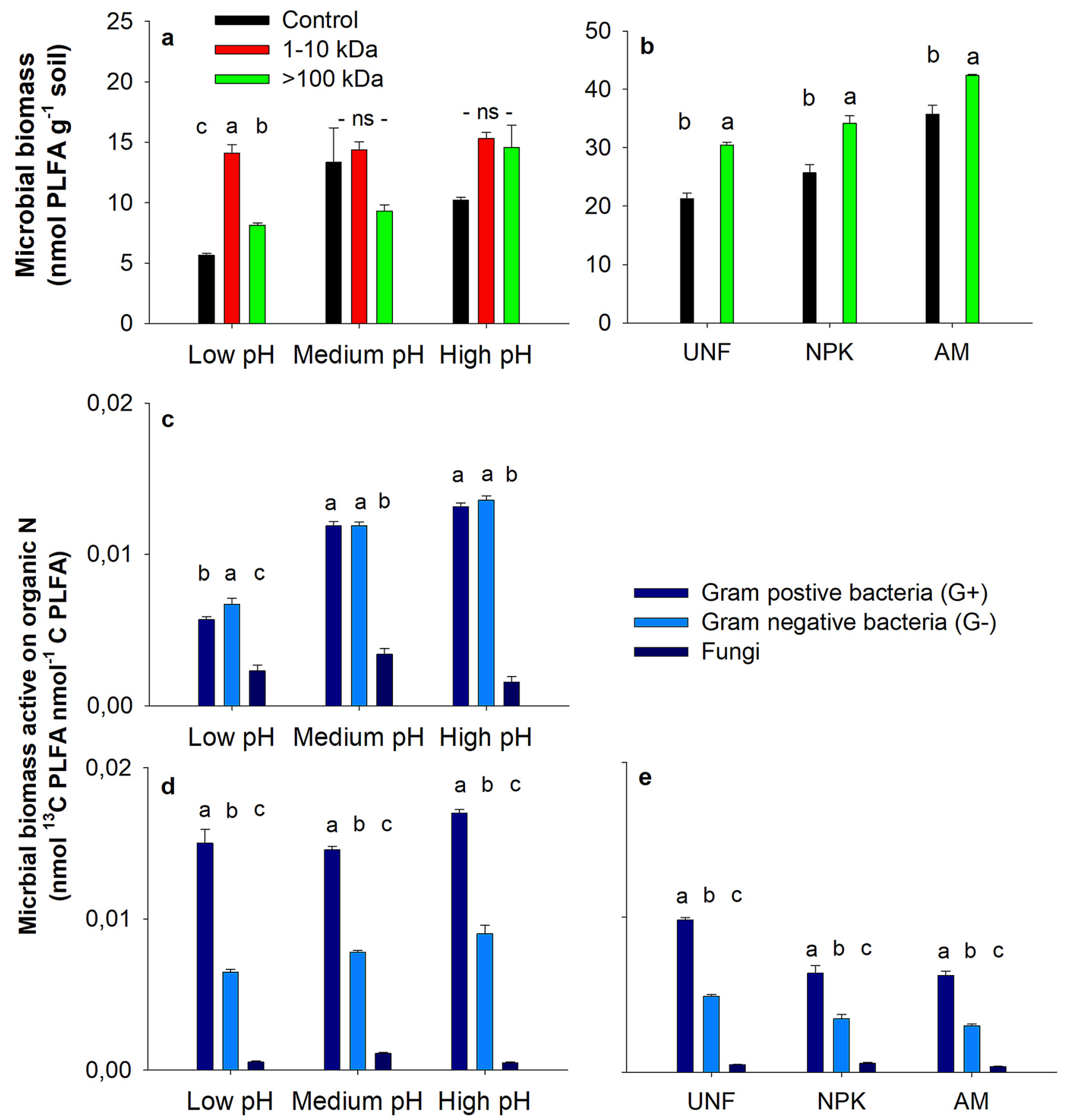

Figure 3. Microbial biomass and specific activity of ${ }^{13} \mathrm{C}$ from added organic $\mathrm{N}$ fractions in the Jyndevad and Askov soils. Total PLFA after 14 days of incubation in control added water, the $1-10 \mathrm{kDa}$ fraction, and the $>100 \mathrm{kDa}$ fraction for the low, medium and high $\mathrm{pH}$ Jyndevad soils (a), Total PLFA after 14 days of incubation in control added water and the $>100 \mathrm{kDa}$ fraction for the unfertilized (UNF), mineral fertilized (NPK), and animal manure (AM) fertilized Askov soil (b), Specific ${ }^{13} \mathrm{C}$ incorporation in gram-positive, gramnegative and fungal PLFAs in Jyndevad soils added the $1-10 \mathrm{kDa}$ fraction $(\mathbf{c})$, Specific ${ }^{13} \mathrm{C}$ incorporation in gram-positive, gram-negative and fungal PLFAs in Jyndevad soils added the $>100 \mathrm{kDa}$ fraction (d), and Specific ${ }^{13} \mathrm{C}$ incorporation in gram-positive, gram-negative and fungal PLFAs in Askov soils added the $>100 \mathrm{kDa}$ fraction (e). Significant differences within treatments are marked by different letter above the bars (error bars are s.e.m., $n=4)$.

\section{Materials and methods}

Soils came from the Jyndevad and Askov long-term field experiments (LTE) in Denmark. The Jyndevad LTE on liming and phosphorus was initiated in $1942^{20}$ on a coarse sandy soil (Table S1) cultivated with spring barley 


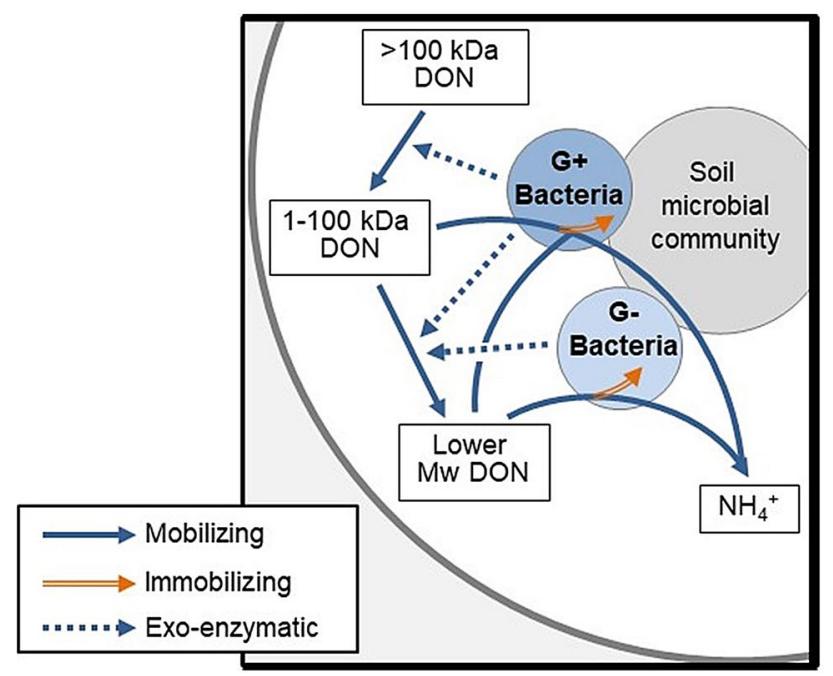

Figure 4. The suggested routes of microbial turnover of large organic $\mathrm{N}$ in soil. The suggested route over 14 days of protein-size (>100 kDa) organic $\mathrm{N}$ turnover via gram-positive $(\mathrm{G}+$ ) exo-enzymatic depolymerization to peptides directly assimilated by gram-positive bacteria with direct gram-positive bacterial uptake of organic $\mathrm{N}$ compounds above the present $0.6 \mathrm{kDa}$ molecular size threshold. Gram-negative $(\mathrm{G}-$ ) bacteria rely on organic $\mathrm{N}$ compounds below the $0.6 \mathrm{kDa}$ molecular size threshold and are thus dependent on exo-enzymatic actions releasing lower molecular size organic $\mathrm{N}$ compounds.

for at least 30 years. The soil was sampled in August 2015 from the plough layer $(5-20 \mathrm{~cm})$ of the V1 field in the treatments receiving 0,4 , and $12 \mathrm{Mg}$ lime ha $^{-1}$ every 5-7 years and yearly doses of $15.6 \mathrm{~kg} \mathrm{P} \mathrm{ha}^{-1} \mathrm{year}^{-1}$. At the time of soil sampling contrasting $\mathrm{pH}_{\mathrm{CaCl} 2}$ levels of 3.6 (low pH), 5.4 (medium pH), and 7.1 (high pH) were established in the three treatments. In Denmark, $10 \%$ of coarse sandy soils on the glacial outwash plain in the Western part of Jutland have a $\mathrm{pH}_{\mathrm{CaCl}}$ below 5.4, and 48 percent of the soils in the area have a $\mathrm{pH}_{\mathrm{CaCl} 2}$ between 5.5 and 5.9 based on 33.357 soil samples ${ }^{44}$. The Askov LTE on animal manure and mineral fertilizers was initiated in $1894^{21}$ on a sandy loam soil in an arable crop rotation (Table S2). The soil was sampled in October 2015 from the plough layer $\left(5-20 \mathrm{~cm}\right.$ ) of the treatments designated unfertilized, $1 \frac{1}{2}$ mineral fertilizer (NPK), and 1 1 $1 \frac{2}{2}$ animal manure (AM) treatments of the B3 field. Annually, the 11/2 NPK and 1 1/2 AM treatments have received, on average $150 \mathrm{~kg}$ total- $\mathrm{N}, 30 \mathrm{~kg} \mathrm{P}$ and $120 \mathrm{~kg} \mathrm{~K} \mathrm{ha}^{-1}$ in mineral fertilizer and animal manure (slurry since 1974), respectively. All soils were sieved $(4 \mathrm{~mm})$ to remove visible roots and stored at $2{ }^{\circ} \mathrm{C}$ until the incubation experiment in September 2015 for Jyndevad soils and October 2015 for Askov soils.

Organic $\mathrm{N}$ fractions were produced from greenhouse grown triple-labeled $\left({ }^{14} \mathrm{C},{ }^{13} \mathrm{C},{ }^{15} \mathrm{~N}\right){ }^{45}$ white clover shoots using a screw press and subsequent Mw size fraction of the juice ${ }^{19}$ into the fractions: $1-10$ and $>100 \mathrm{kDa}$. Briefly, white clover grown in sterile sand received a standard nutrient solution supplemented with ${ }^{15} \mathrm{~N}$-labeled $\left({ }^{15} \mathrm{NH}_{4}\right)_{2} \mathrm{SO}_{4}$ (98 at\%) and was C-labeled with ${ }^{14} \mathrm{CO}_{2}$ and ${ }^{13} \mathrm{CO}_{2}$ via labeled bicarbonate (for ${ }^{13} \mathrm{C} 99$ at $\%$ ) as described for ${ }^{14} \mathrm{CO}_{2}$ by Rasmussen et al. (2008). Upon harvest, clover shoots were pressed in a screw press ${ }^{46}$ to obtain a juice, which was passed through a $0.45 \mu \mathrm{m}$ filter and $\mathrm{Mw}$ sizes fractionated using $20 \mathrm{ml}$ centrifugal filter tubes with a pore size of 1,10 and $100 \mathrm{kDa}$ (Macrosep Advance, Pall Corporation, Ann Arbor, MI, USA). The organic $\mathrm{N}$ fractions were characterized for total $\mathrm{C}$ and $\mathrm{N}$, bulk isotopic, and amino acid specific composition as described in Enggrob et al. ${ }^{19}$ (Table S3, Fig. S1). The organic N fractions were incubated in packed microlysimeters holding $12 \mathrm{~g}$ field moist soil. The micro-lysimeters were constructed from inserts in $50 \mathrm{~mL}$ centrifuge tubes (Fig. S4) to allow rapid recovery of soil solution by centrifugation upon termination of incubation. Incubation time was one-hour and 14 days at room temperature $\left(22^{\circ} \mathrm{C}\right)$ and all soil amendments were made in four replicates. The one-hour incubation allowed the determination of organic $\mathrm{N}$ sorption. The 14 days incubation was chosen for the mineralization response based on the assumption that if sorption controls mineralization this would be the time when labeled organic $\mathrm{N}$ had been depleted from the soil solution. The organic $\mathrm{N}$ fractions were added in low amounts equivalent to $100-190 \mu \mathrm{g} \mathrm{C} \mathrm{g}^{-1}$ soil and 9-40 $\mu \mathrm{g} \mathrm{N} \mathrm{g}{ }^{-1}$ soil in $2 \mathrm{~mL}$ water, and sufficiently low to have a minor or no influence on the concentration of extractable amino acids in soil (Fig. S2). The microlysimeters were incubated in the dark in $1 \mathrm{~L}$ glass jars at room temperature $\left(22^{\circ} \mathrm{C}\right)$ with a beaker holding $1 \mathrm{~mL}$ of $0.5 \mathrm{M} \mathrm{NaOH}$ to trap respired ${ }^{14} \mathrm{CO}_{2}$. Liquid scintillation cocktail (OptiPhase HiSafe3, PerkinElmer, Waltham, MA, USA) was added to the trap solution and ${ }^{14} \mathrm{C}$-activity counted on a Tri-Carb $2910 \mathrm{TR}$ Liquid Scintillation Analyser (PerkinElmer, Waltham, MA, USA). Both organic N fractions were incubated in the Jyndevad soils, whereas the $>100 \mathrm{kDa}$ fraction was incubated in the Askov soils for comparison of results across two soil types. Control treatments with the addition of $2 \mathrm{~mL}$ water instead of organic $\mathrm{N}$ were run for all soils and sampling times.

Upon termination, $8 \mathrm{~mL}$ of water was added to the micro-lysimeters and subsequently centrifuged for $5 \mathrm{~min}$ at $5000 \mathrm{~g}$ followed by the addition of $10 \mathrm{~mL}$ of water with repeated centrifugation. The two solutions were pooled to give one sample of $20 \mathrm{~mL}$ containing the soluble $\mathrm{N}$ fractions. Next, the soil in the micro-lysimeters was washed in a similar manner with two times $10 \mathrm{~mL} 1 \mathrm{M} \mathrm{KCl}$. The water solutions were immediately filtered through $0.45 \mu \mathrm{m}$ Macrosep centrifuge filters (Pall Corporation, New York, USA) and the filtrates were sampled 
for ${ }^{14} \mathrm{C}$-analysis (see above). The remaining liquid samples were stored frozen until further analysis of total $\mathrm{C}$ and $\mathrm{N}$ content and ${ }^{13} \mathrm{C}$ and ${ }^{15} \mathrm{~N}$ isotope composition. After the final $\mathrm{KCl}$ wash the soil was immediately recovered from the micro-lysimeters and stored frozen until further analysis. No ${ }^{13} \mathrm{C}$ was detected in soil solutions after 14 days of incubation (data not shown).

Soil solution samples were freeze-dried, re-dissolved in $1 \mathrm{~mL}$ MilliQ water (Synergy System, Millipore, Molsheim, France), transferred to tin capsules before analysis of total $\mathrm{C}$ and $\mathrm{N}$ content and ${ }^{13} \mathrm{C}$ and ${ }^{15} \mathrm{~N}$ stable isotope composition. Analyses were performed on a Flash Elemental Analyser (Thermo Scientific, Hvidovre, Denmark) coupled via a TCD to an isotope ratio mass spectrometer (Delta V Plus IRMS, Thermo Scientific, Hvidovre, Denmark). Mass spectrometer related parameters were controlled by the Isodat software version 3.0 (Thermo Scientific, Hvidovre, Denmark). All $\delta^{13} \mathrm{C}$ values are reported relative to the Vienna PeeDee Belemnite (VPDB) international isotope standard. All $\delta^{15} \mathrm{~N}$ values are reported relative to the $\delta^{15} \mathrm{~N}$ values of atmospheric $\mathrm{N}_{2}$.

Soil samples were freeze-dried and homogenized by ball milling to allow representative sub-sampling. Jyndevad soils with added $1-10$ and $>100 \mathrm{kDa}$ organic $\mathrm{N}$ fractions and Askov soils with added $>100 \mathrm{kDa}$ fraction (all incubated for 14 days) underwent compound-specific isotope analysis aimed at determining organic $\mathrm{N}$ bound in amino acids (AA-SIP) and biomarkers for active microbial biomass (PLFA-SIP). For AA-SIP, 800 mg freezedried soil was weighed into $16 \times 100$ soda-lime disposable test tubes (Duran Group, Mainz, Germany) with the addition of $2 \mathrm{~mL} 6 \mathrm{M} \mathrm{HCl}$ and hydrolyzed for $20 \mathrm{~h}$ at $110^{\circ} \mathrm{C}$. To remove solids and lipophilic compounds $4 \mathrm{~mL}$ $\mathrm{n}$-hexane/dichloromethane $(6: 5, \mathrm{v} / \mathrm{v})$ was added and vortexed for $30 \mathrm{~s}$ with centrifugation ( $1600 \mathrm{rpm}$ at $2 \mathrm{~min})$. After mixing and centrifugation, the aquatic phase was transferred through a Pasteur pipette lined with glass wool, to remove visible floating particles from the aquatic phase, followed by washing the Pasteur pipette lined with glass wool by with $2 \times 0.5 \mathrm{~mL} 0.1 \mathrm{M} \mathrm{HCl}$ into new test tubes. The remaining sample preparation (purification and derivatization of amino acids) along with the GC-C-IRMS analysis was done as described in Enggrob et al. ${ }^{19}$. Deviations from the protocol included an additional freeze-drying step during purification following the addition of the internal standard $(300 \mu \mathrm{l} 2.5 \mathrm{M}$ norLeucine) and before the sample filtration on resin columns. The amino acids: asparagine and aspartate (Asx), glutamine and glutamate (Glx), and Proline and Threonine (Pro/Thr) elute together in the GC-C-IRMS analysis of the acid hydrolyzed samples. For PLFA-SIP, $2.5 \mathrm{~g}$ freezedried soil was used to isolate phospholipids by a Bligh-Dyer single-phase extraction followed by a solid-phase extraction on silicic acid columns and an alkaline transesterification ${ }^{47,48}$. The PLFAs were analyzed for isotopic composition by a GC-C-IRMS at the Stable isotope service laboratory, Department of Biology, Lund University, Sweden. Individual PLFAs were assigned to specific microbial groups ${ }^{49-51}$ (Table S4); both specified and unspecified PLFAs were used for estimating active microbial biomass.

Statistical analyses. For comparisons, the effect of treatments (soil $\mathrm{pH}$ levels and fertility) and the $\mathrm{Mw}$ organic $\mathrm{N}$ fractions on intact ${ }^{13} \mathrm{C}$ or ${ }^{15} \mathrm{~N}$ labeled amino acids remaining in soil, microbial biomass, and ${ }^{13} \mathrm{C}$ incorporation into PLFA was conducted using linear mixed-effects models with replicate as a random factor. Subsequent pairwise comparisons of the means were conducted using the Tukey post hoc analysis. Data were log-transformed (when required) to achieve homogeneity of variances and normality. Significance testing was conducted at $p<0.05$. All statistical analyses were conducted in RStudio (R Core Team, 2016, URL https:// www.R-project.org/).

\section{Data availability}

Data available on request from the authors.

Received: 11 April 2020; Accepted: 21 August 2020

Published online: 28 September 2020

\section{References}

1. Paustian, K. et al. Climate-smart soils. Nature 532, 49-57. https://doi.org/10.1038/nature17174 (2016).

2. Knicker, H. Soil organic N-An under-rated player for C sequestration in soils?. Soil Biol. Biochem. 43, 1118-1129 (2011).

3. Schmidt, M. W. I. et al. Persistence of soil organic matter as an ecosystem property. Nature 478, 49-56 (2011).

4. Lehmann, J. \& Kleber, M. The contentious nature of soil organic matter. Nature 528, 60-68. https://doi.org/10.1038/nature16069 (2015).

5. Cotrufo, M. F. et al. Formation of soil organic matter via biochemical and physical pathways of litter mass loss. Nat. Geosci. 8, 776. https://doi.org/10.1038/ngeo2520 (2015).

6. Liang, C., Schimel, J. P. \& Jastrow, J. D. The importance of anabolism in microbial control over soil carbon storage. Nat. Microb. https://doi.org/10.1038/nmicrobiol.2017.105 (2017).

7. Czaban, W., Rasmussen, J., Nicolaisen, M. \& Fomsgaard, I. S. Dissipation kinetics of asparagine in soil measured by compoundspecific analysis with metabolite tracking. Biol. Fertil. Soils 52, 911-916. https://doi.org/10.1007/s00374-016-1132-6 (2016).

8. Farrell, M. et al. Rapid peptide metabolism: a major component of soil nitrogen cycling?. Global Biogeochem. Cycles 25, 107760 (2011).

9. Apostel, C., Dippold, M. A., Bore, E. \& Kuzyakov, Y. Sorption of Alanine changes microbial metabolism in addition to availability. Geoderma 292, 128-134. https://doi.org/10.1016/j.geoderma2017.01.016 (2017).

10. Khan, K. S., Mack, R., Castillo, X., Kaiser, M. \& Joergensen, R. G. Microbial biomass, fungal and bacterial residues, and their relationships to the soil organic matter C/N/P/S ratios. Geoderma 271, 115-123. https://doi.org/10.1016/j.geoderma.2016.02.019 (2016).

11 Miltner, A., Bombach, P., Schmidt-Brücken, B. \& Kästner, M. SOM genesis: microbial biomass as a significant source. Biogeochemistry 111, 1-15 (2012).

12. Lavallee, J. M., Soong, J. L. \& Cotrufo, M. F. Conceptualizing soil organic matter into particulate and mineral-associated forms to address global change in the 21st century. Glob. Change Biol. 26, 261-273. https://doi.org/10.1111/gcb.14859 (2020).

13 Cotrufo, M. F., Ranalli, M. G., Haddix, M. L., Six, J. \& Lugato, E. Soil carbon storage informed by particulate and mineral-associated organic matter. Nat. Geosci. 12, 989. https://doi.org/10.1038/s41561-019-0484-6 (2019). 
14. Nannipieri, P. \& Eldor, P. The chemical and functional characterization of soil $\mathrm{N}$ and its biotic components. Soil Biol. Biochem. 41, 2357-2369 (2009).

15. Schimel, J. P. \& Bennett, J. Nitrogen mineralization: challenges of a changing paradigm. Ecology 85, 591-602 (2004).

16. Jan, M. T., Roberts, P., Tonheim, S. K. \& Jones, D. L. Protein breakdown represents a major bottleneck in nitrogen cycling in grassland soils. Soil Biol. Biochem. 41, 2272-2282. https://doi.org/10.1016/j.soilbio.2009.08.013 (2009).

17. Jones, D. L. \& Kielland, K. Amino acid, peptide and protein mineralization dynamics in a taiga forest soil. Soil Biol. Biochem. 55, 60-69 (2012).

18. Mariano, E., Jones, D. L., Hill, P. W. \& Trivelin, P. C. O. Mineralisation and sorption of dissolved organic nitrogen compounds in litter and soil from sugarcane fields. Soil Biol. Biochem. 103, 522-532. https://doi.org/10.1016/j.soilbio.2016.10.004 (2016).

19. Enggrob, K. L., Larsen, T., Larsen, M., Elsgaard, L. \& Rasmussen, J. The influence of hydrolysis and derivatization on the determination of amino acid content and isotopic ratios in dual labeled (13C, 15N) white clover. Rapid Commun Mass Spectrom https:// doi.org/10.1002/rcm.8300 (2018).

20. Rubaek, G. H. In Long-term field experiments-a unique research platform (eds Christensen, B. T. et al.) (Aarhus University, Denmark, 2008).

21. Christensen, B. T., Petersen, J. \& Trentemoller, U. M. The Askov long-term experiments on animal manure and mineral fertilizers: The Lermarken site 1894-2004. Report No. 121 (2006).

22. Dumont, M. G. \& Murrell, J. C. Stable isotope probing-linking microbial identity to function. Nat. Rev. Microbiol. 3, 499-504. https://doi.org/10.1038/nrmicro1162 (2005).

23. Jones, D. L. \& Hodge, A. Biodegradation kinetics and sorption reactions of three differently charged amino acids in soil and their effects on plant organic nitrogen availability. Soil Biol. Biochem. 31, 1331-1342 (1999).

24. Gonod, L. V., Jones, D. L. \& Chenu, C. Sorption regulates the fate of the amino acids lysine and leucine in soil aggregates. Eur. J. Soil Sci. 57, 320-329 (2006).

25. Kogel-Knabner, I. \& Rumpel, C. In Advances in Agronomy, vol 149 (ed. Sparks, D. L.) 1-48 (Elsevier, Amsterdam, 2018).

26. Kirchman, D. L., Newell, S. Y. \& Hodson, R. E. Incorporation versus biosynthesis of leucine - implications for measuring rates of protein-synthesis and biomass production by bacteria in marine systems. Mar. Ecol. Prog. Ser. 32, 47-59. https://doi.org/10.3354/ meps032047 (1986).

27. Dippold, M. A. \& Kuzyakov, Y. Biogeochemical transformations of amino acids in soil assessed by position-specific labelling. Plant Soil 373, 385-401. https://doi.org/10.1007/s11104-013-1764-3 (2013).

28. Simelyte, E., Rimpilainen, M., Zhang, X. \& Toivanen, P. Role of peptidoglycan subtypes in the pathogenesis of bacterial cell wall arthritis. Ann. Rheum. Dis. 62, 976-982. https://doi.org/10.1136/ard.62.10.976 (2003).

29. Schneewind, O. \& Missiakas, D. M. Protein secretion and surface display in Gram-positive bacteria. Philos. Trans. R. Soc. B Biol. Sci. 367, 1123-1139. https://doi.org/10.1098/rstb.2011.0210 (2012).

30. Vollmer, W., Blanot, D. \& de Pedro, M. A. Peptidoglycan structure and architecture. FEMS Microbiol. Rev. 32, 149-167. https:// doi.org/10.1111/j.1574-6976.2007.00094.x (2008).

31. Tamez-Hidalgo, P., Christensen, B. T., Lever, M. A., Elsgaard, L. \& Lomstein, B. A. Endospores, prokaryotes, and microbial indicators in arable soils from three long-term experiments. Biol. Fertil. Soils 52, 101-112. https://doi.org/10.1007/s00374-015-1057-5 (2016).

32. Hemkemeyer, M., Christensen, B. T., Martens, R. \& Tebbe, C. C. Soil particle size fractions harbour distinct microbial communities and differ in potential for microbial mineralisation of organic pollutants. Soil Biol. Biochem. 90, 255-265. https://doi.org/10.1016/j. soilbio.2015.08.018 (2015).

33. Suarez-Tapia, A., Thomsen, I. K., Rasmussen, J. \& Christensen, B. T. Residual N effect of long-term applications of cattle slurry using winter wheat as test crop. Field Crops Res. 221, 257-264. https://doi.org/10.1016/j.fcr.2017.10.013 (2018).

34. Castellano, M. J., Mueller, K. E., Olk, D. C., Sawyer, J. E. \& Six, J. Integrating plant litter quality, soil organic matter stabilization, and the carbon saturation concept. Glob. Change Biol. 21, 3200-3209. https://doi.org/10.1111/gcb.12982 (2015).

35. Jensen, J. L., Schjonning, P., Christensen, B. T. \& Munkholm, L. J. Suboptimal fertilisation compromises soil physical properties of a hard-setting sandy loam. Soil Res. 55, 332-340. https://doi.org/10.1071/sr16218 (2017).

36. Madigan, M. T., Bender, K. S., Buckley, D. H., Sattley, W. M. \& Stahl, D. A. Brock Biology of Microorganisms 15th edn. (Pearson Education Limited, London, 2018)

37. Rousk, J. et al. Soil bacterial and fungal communities across a pH gradient in an arable soil. ISME J. 4, 1340-1351 (2010).

38. Burns, R. G. In Soil Enzymes (ed. Burns, R. G.) (Academic Press, Cambridge, 1978).

39. Detmers, F. J. M., Kunji, E. R. S., Lanfermeijer, F. C., Poolman, B. \& Konings, W. N. Kinetics and specificity of peptide uptake by the oligopeptide transport system of Lactococcus lactis. Biochemistry 37, 16671-16679. https://doi.org/10.1021/bi981712t (1998).

40. Scherrer, R., Beaman, T. C. \& Gerhardt, P. Macromolecular sieving by dormant spore of bacillus-cereus. J. Bacteriol. 108, 868-870 (1971).

41. Nannipieri, P., Trasar-Cepeda, C. \& Dick, R. P. Soil enzyme activity: a brief history and biochemistry as a basis for appropriate interpretations and meta-analysis. Biol. Fertil. Soils 54, 11-19. https://doi.org/10.1007/s00374-017-1245-6 (2018).

42. Simpson, J., Warren, C. \& Adams, P. Potential protease activity and organic nitrogen concentration are rapid tests and accurate indicators of $\mathrm{N}$-availability in Tasmanian Eucalyptus nitens plantations. Soil Biol. Biochem. 115, 152-160. https://doi.org/10.1016/j. soilbio.2017.08.015 (2017).

43. Lipson, D. \& Nasholm, T. The unexpected versatility of plants: organic nitrogen use and availability in terrestrial ecosystems. Oecologia 128, 305-316 (2001).

44. Mortensen, R. M. In Oversigt over Landsforsøgene 2016 (ed. Pedersen, J. B.) 255-257 (Aarhus, SEGES, 2016)

45. Rasmussen, J., Gjettermann, B., Eriksen, J., Jensen, E. S. \& Hogh-Jensen, H. Fate of N-15 and C-14 from labelled plant material: Recovery in perennial ryegrass-clover mixtures and in pore water of the sward. Soil Biol. Biochem. 40, 3031-3039 (2008).

46. Colas, D., Doumeng, C., Pontalier, P. Y. \& Rigal, L. Green crop fractionation by twin-screw extrusion: Influence of the screw profile on alfalfa (Medicago sativa) dehydration and protein extraction. Chem. Eng. Process. 72, 1-9. https://doi.org/10.1016/j. cep.2013.05.017 (2013).

47. Petersen, S. O. \& Klug, M. J. Effects of sieving, storage, and incubation-temperature on the phospholipid fatty-acid profile of a soil microbial community. Appl. Environ. Microbiol. 60, 2421-2430 (1994).

48. Petersen, S. O., Frohne, P. S. \& Kennedy, A. C. Dynamics of a soil microbial community under spring wheat. Soil Sci. Soc. Am. J. 66, 826-833 (2002).

49. Fierer, N., Schimel, J. P. \& Holden, P. A. Variations in microbial community composition through two soil depth profiles. Soil Biol. Biochem. 35, 167-176. https://doi.org/10.1016/s0038-0717(02)00251-1 (2003).

50. Stromberger, M. E., Keith, A. M. \& Schmidt, O. Distinct microbial and faunal communities and translocated carbon in Lumbricus terrestris drilospheres. Soil Biol. Biochem. 46, 155-162. https://doi.org/10.1016/j.soilbio.2011.11.024 (2012).

51. Frostegard, A., Baath, E. \& Tunlid, A. Shifts in the structure of soil microbial communities in limed forests as revealed by phospholipid fatty-acid analysis. Soil Biol. Biochem. 25, 723-730. https://doi.org/10.1016/0038-0717(93)90113-p (1993). 


\section{Acknowledgements}

We thank L. Elsgaard, G.H. Rubæk, Z. Liang and J.E. Olesen for discussions. The study was financially supported by The Independent Research Fund Denmark-Technology and Production (Project No. 1335-00760B).

\section{Author contributions}

K.L.E. and J.R. designed and executed the experiment and analysis; K.L.E. performed statistical analysis; K.L.E., T.L. and J.R. made AA-SIP fingerprinting interpretations; L.P. and K.L.E made PLFA-SIP interpretations and statistical analysis; K.L.E. and J.R. drafted the manuscript; all authors revised the manuscript and approved the final version.

\section{Competing interests}

The authors declare no competing interests.

\section{Additional information}

Supplementary information is available for this paper at https://doi.org/10.1038/s41598-020-72696-y.

Correspondence and requests for materials should be addressed to J.R.

Reprints and permissions information is available at www.nature.com/reprints.

Publisher's note Springer Nature remains neutral with regard to jurisdictional claims in published maps and institutional affiliations.

(c) (i) Open Access This article is licensed under a Creative Commons Attribution 4.0 International License, which permits use, sharing, adaptation, distribution and reproduction in any medium or format, as long as you give appropriate credit to the original author(s) and the source, provide a link to the Creative Commons licence, and indicate if changes were made. The images or other third party material in this article are included in the article's Creative Commons licence, unless indicated otherwise in a credit line to the material. If material is not included in the article's Creative Commons licence and your intended use is not permitted by statutory regulation or exceeds the permitted use, you will need to obtain permission directly from the copyright holder. To view a copy of this licence, visit http://creativecommons.org/licenses/by/4.0/.

(C) The Author(s) 2020 